\title{
Investigation of the Association of Blood Pressure with Some Haematological Parameters of University Students of Niger Delta Descendant, Nigeria
}

\section{Azuonwu 0*, Nnenna I and Iheanacho LN}

Department of Medical Laboratory Science, Rivers State University of Science and Technology, Nigeria

*Corresponding author: Azuonwu Obioma, Department of Medical Laboratory Science, Faculty of Sciences, Rivers State University of Science and Technology, Nkpolu, Port Harcourt, Nigeria, E-mail: bimajacobs@yahoo.co.uk

\section{Research Article \\ Volume 2 Issue 1}

Received Date: November 13, 2017

Published Date: January 02, 2018

DOI: $10.23880 /$ mjccs- 16000125

\section{Abstract}

It is generally believed that functional disturbances of body systems could possibly influence the body blood pressures and thus, could as well alter some hematological parameters of an individual in stressed condition. This study was aimed at determining the influence of blood pressure on the hematological parameters of students in our local community, thus, it is firmly believed that data generated will be used for prompt management of potential illness that could be linked to such health conditions. A comparative epidemiological in/out school based survey; and a purposive sampling technique was explored for population choice. However, disproportionate stratified sampling technique was used to select one hundred apparently healthy subjects, comprising of 60 students and 40 controls of equal sex distribution within both groups. Blood pressure was estimated with the Omron sphygmomanometer (Japan) and blood samples were analyzed using the DX500 Beckman Coulter (USA). While Westergren method was explored for erythrocyte sedimentation rate. Results were presented as mean \pm SD while inference was deduced when analyzed using SPSS version 21 for unpaired $t$ test and ANOVA at $5 \%$. The blood pressure readings of the male students $119 / 82 \pm 12 / 10 \mathrm{mmHg}$ and females students $124 / 82 \pm 14 / 10 \mathrm{mmHg}$ (systolic/diastolic) respectively revealed no statistically significant difference at $\mathrm{p}>0.05$ in both male and female students population. The indices of the erythrocyte population showed significant $(\mathrm{P}<0.05)$ sex disparity for both the Haemoglobin and Packed Cell Volume, likewise the result of ESR whereas, the white blood cell count showed no variation $(p>0.05)$ between the male and female students. The control subjects showed that almost all parameters investigated were comparatively similar $(\mathrm{p}>0.05)$ except the haemoglobin parameter which showed a discrepancy $(p<0.05)$ between the male control and female controls. Also, among male students and control males showed mean difference $(\mathrm{P}<0.05)$ in the age, WBC and ESR while; the observation revealed an agreement in the mean values of the blood pressure, haemoglobin and Packed Cell Volume for both the male students and control males. However, same sex comparison between female students and female controls revealed no indication of statistical variations $(p>0.05)$ in all 


\section{Medical Journal of Clinical Trials \& Case Studies}

the mean values. This study has shown that haematological parameters and blood pressures in students remained within the acceptable baseline values except in a disordered state. Hence, there is need for routine checks in more regular intervals among the physically active and vulnerable groups like the students population

Keywords: Haematological Parameters; Blood Pressure; Students; High risk group; Age; Sex; Niger Delta

Abbreviation: HTN: Hypertension; SBP: Systolic Blood Pressure; BP: Blood Pressure; DBP: Diastolic Blood Pressure; ESR: Erythrocyte Sedimentation Rate.

\section{Introduction}

Blood pressure has generally been likened to increase with increasing age therefore, not supposedly to be observed among students as the population of students is mainly young population [1]. Several studies have documented that there is an increase in the prevalence of hypertension (HTN) in developed and underdeveloped nations [2-5]. Furthermore, some scholars have reported that pre-hypertension can start in adolescence even HTN, perhaps in the early stages of life, and persist into adulthood [6,7]. Moreover, there are risk factors which could predispose an individual to HTN irrespective of the age. Nonetheless, recent study opined that the changes in BMI between the ages of seven and fifteen years could possibly have a significant detrimental health effect on the systolic blood pressure data (SBP) at the age of fifteen [8]. Nevertheless, epidemiological transition which involves replacement of infectious diseases by chronic diseases is often played out as some of the risk factors of chronic diseases are seen among the population of the young ones depending on some determinant cofounders like cultural, political, socio-economical (standards of living, health habits/lifestyle, nutrition etc) particularly in those living at low quality of life with visible health intervention deprivation especially in our remote communities.

Nevertheless, due to the increasing morbidity and mortality statistics of the health burden which had attracted negative repercussions towards the quality of life, these could be linked to some socio-economic factors that tend to promote the chronic diseases like hypertension and it's complicating conditions as it tends to affect the blood indices of the affected subjects massively [9]. Presently developing countries like those of the Sub-Saharan African are experiencing one of the most rapid epidemiological transitions characterized by increasing urbanization and changing lifestyle, which in turn have raised the incidence of non-communicable diseases, especially on campus where the university environment is often regarded as a mini global community [10]. The prevalence of overweight and obesity is growing in Sub-Saharan African countries, while the competing epidemics of malnutrition statistics is still on the increasing trend [10-12]. These factors can be verified in different populations, including college students, nonetheless, it is strongly believed globally that upon getting admission into university, students undergo lifestyle modification and thus, these different lifestyle changes could hugely support the emergence of one or several risk factors like increasing the sedentary lifestyle/physical inactivity, substance abuse consumption of substances like tobacco and alcoholic beverages and bad eating habits are some of the new ways of life of some students outside home, where they could no longer be monitored closely by their parents $[13,14]$.

Nevertheless, it is firmly suggested that in pre-pubertal stage in humans, no major difference can be found between the sexes in red blood cell indices and serum ferritin concentrations [15]. However, Rushton, et al. (2010) reported that only after the onset of menstruation and other hormonal changes does a specific difference emerge. Nonetheless, it is also well documented opinion that haematological baseline values vary in different population groups and in different geographical areas. It is strongly opined that variations are usually due to age, sex, attitude, activities, environmental factors and social differences [16].

Furthermore, the mechanism underlying the blood pressure and haematological parameters association have been explained with the blood fluid mechanics principle. Nonetheless, the volume of fluid or blood volume which is the amount of blood that is present in the body is often regarded as one of the main determinant factor. The more blood present in the body, the higher the rate of blood returns to the heart and the resulting cardiac output. There is a relationship between dietary salt intake and increased blood volume, potentially resulting in higher arterial pressure, though this varies in individual and is highly dependent on autonomic nervous system response and the renin-angiotensin system [17]. 


\section{Medical Journal of Clinical Trials \& Case Studies}

Nonetheless, quantitative and physiological determinants of resistance to blood flow includes vessel diameter (or radius), vessel length due to contraction and relaxation of the vascular smooth muscle in the wall of the blood vessel and viscosity of the blood. The higher the resistance of blood vessel, the higher the arterial pressure upstream from the resistance to blood flow, however certain medical conditions can change the viscosity of the blood. For Instance, anaemia (low red blood cell concentration), reduces viscosity, whereas increased red blood cell concentration increases viscosity. It is strongly suggested that aspirin and other related "blood thinner" drugs depressed the viscosity of blood, but contrarily to these, evidence based studies have found that they act by reducing the tendency of the blood to clot in the system of the subject in question [18].

Furthermore, there is often a large variation from person to person as arterial pressure also varies in individuals from moment to moment. Additionally, the average of any given population may have a questionable correlation with its general health and activities; thus, the relevance of such average values is equally questionable [19]. In consideration of the above, University students are prone to so many factors that tends to trigger variation in blood pressures and consequently affect their haematological parameters. This is believed to be in line with the huddles and stress situations in the University system education, especially in developing communities which are often hinges on regular long lectures duration without break, series of assignments with little or no functional learning aids, junk foods and most importantly examination of students without adequate gap or space from the beginning of the examination to the end. However, measurement of blood pressure is vital in ascertaining the true health condition of individual, this is because its status affects the physiology of the entire body system and even the haematological parameters which are key players in the normal functioning of the body are also affected. More so, blood pressure triggers functional disturbances in many systems of the body thus, there is a possibility that increase or decrease in blood pressure can alter the haematological parameters of the body system [20]. Interestingly the haematological parameters that were considered in this present study include red cell Indices (haemogloblin\& packed cell volume), erythrocyte sedimentation rate and white blood cells alongside blood pressure estimation, thus there is evidence of paucity of epidemiological information on the above subjects matter amongst the high risk group like the students population in Niger Delta communities. Nevertheless, most of studies in the region did not cover this group, thus it is firmly believed that data generated from the study will certainly form a strong epidemiological data that would help the policy makers and relevant health agencies to articulate their views toward prompt diagnosis of the risk factors that would promote robust planning, implementation of health policies and underpin disease management outcome, even in good time.

\section{Description of the Study Location}

Rivers State University (RVSU), formerly Rivers State University of Science and Technology, is a University located in the Diobu area of Port Harcourt, Rivers State, Nigeria. However, Diobu consist of three focal extensions, which includes Mile 1, Mile 2 i.e. from the University back gate and Mile 3 i.e. from the University main gate. University of Science and Technology is on the northwest of Diobu, it covers to Eagle Island which is to the southwest part of Diobu. The regional co-ordinates are: 447'24"N, 659'36"E (Latitude: 4.772152; Longitude: 6.994514 ) and time zone is WAT (UTC+1). The University has staff strength of 3,000 and a student population of 22,400 as of 2017 . It is the first technological university in Nigeria and also the first university to be situated within the Niger Delta. Historically, the Rivers State University of Science and Technology was established in 1972 as the College of Science and Technology. It was granted independent university status in 1980 and was renamed from College of Science and Technology to Rivers State University of Science and Technology. It is the only university in Nigeria that is accredited to offer degree programs in Marine Engineering. There are seven faculties in RSU namely: Sciences, Engineering, Law, Management Sciences, Environmental Sciences, Agriculture, Science and Technical Education [21].

\section{Study Design}

A comparative epidemiological in/out school base survey was developed. A purposive sampling technique was used for the population choice; disproportionate technique was used to stratify the study participants into different strata of male and female students and nonstudents as controls.

\section{Inclusion Criteria}

The selection of the participants complied with the following inclusion criteria: being actively enrolled in the university, regular student's age 18 years and above and those who consented to participated. Not previously been diagnosed of high blood pressure and any form of cardio vascular disease. 


\section{Medical Journal of Clinical Trials \& Case Studies}

\section{Excluding Criteria}

Excluding year one/first level students, part time students, those involved in smoking, drinking, family history of hypertension, pregnancy and metabolic diseases were completely removed from participation even those who did not give their consent to participate were removed etc.

\section{Experimental/Method}

\section{Blood Pressure Estimation}

The average of two readings of systolic and diastolic blood pressures was measured sphygmomanometer from OMRON made in Japan. According to the Joint National Committee (JNC) 7 report and Hypertension Guidelines, blood pressure (BP) categories were defined as normal blood pressure if the observed systolic blood pressure (SBP) was between 91 and $120 \mathrm{~mm} \mathrm{Hg}$ or diastolic blood pressure (DBP) was between 61 and $80 \mathrm{~mm} \mathrm{Hg}$; pre-HTN if the observed SBP was between 121 and $139 \mathrm{mmHg}$ or DBP was between 81 and $89 \mathrm{mmHg}$; and considered as HTN if the observed SBP was equal to or above 140 $\mathrm{mmHg}$ and DBP was equal to or above $90 \mathrm{mmHg}$; and finally hypotension was defined as SBP being equal to or less than $90 \mathrm{~mm} \mathrm{Hg}$ or DBP being equal to or less than 60 $\mathrm{mm} \mathrm{Hg}[22,23]$.

\section{Blood Parameter}

Two (2) mls of venous blood was collected, blood was aseptically collected and dispensed into the EDTA bottle. These were mixed properly with a sample mixing machine for uniformity and even distribution of the cells before the assay were conducted. Haematological parameters were analyzed using the DX500 Beckman Coulter (USA).

\section{Statistical Analysis}

The data were analyzed through the Statistical Package for the Social Sciences (SPSS), version 21.0. For the descriptive analysis, measures of central tendency and dispersion were obtained. The Kolmogorov-Smirnov test was applied to assess the normality of the sample. Independent t-test was applied to check for discrepancies within and between groups for the variables studied. The rejection level established for the null hypothesis was lower than or equal to 0.05 (5\%).

\section{Results}

The objective of this study was achieved by comparing haematological parameters and blood pressures of students and controls (non-students), separately for male and female by recruiting one hundred (100) study participants comprising of sixty (60) students, and forty (40) controls which included 30 female and 30 male students with a mean age of $18 \pm 7$ years which were randomly selected. Forty non-students with a mean age $25 \pm 9$ years and comprising 20 females and 20 males were taken as the control group. The test variables were sex matched within groups (i.e. male students vs female students and vice versa for control) and between groups (i.e. students vs non students).

With respect to mean comparison of haematological parameters and blood pressures of students based on gender, the result obtained here revealed the age of the subjects $18 \pm 7$ years for males and $25 \pm 9$ years for females with a statistically significant difference $(\mathrm{P}<0.05)$, $\mathrm{t}_{58}=3.3627, \mathrm{~N}=60$. However, on the other hand, the blood pressure $119 / 82 \pm 12 / 10 \mathrm{mmHg}$ and $124 / 82 \pm$ $14 / 10 \mathrm{mmHg}$ for male and female blood pressures (systolic/diastolic) respectively showed no statistically significant difference at $p>0.05$. The indices of the erythrocyte population showed statistical significant $(\mathrm{P}<0.05)$ even sex disparity for both the Haemoglobin, haematocrit (Packed Cell Volume) and the result of ESR showed statistical significant at $\mathrm{P}<0.05$, ' whereas, the white blood cell (leucocytes) showed no variation $(\mathrm{p}>0.05)$ between the male and female students respectively (Table 1).

\begin{tabular}{|c|c|c|c|c|c|}
\hline Parameters (Mean $\mathbf{\pm}$ SD) & Male Students N=30 & Female Students N=30 & t-test & DF & p-value \\
\hline Age (years) & $18 \pm 7$ & $25 \pm 9$ & 3.3627 & 58 & $\mathrm{P}<0.05$ \\
\hline Systolic B.P (mmHg) & $119 \pm 12$ & $124 \pm 14$ & 1.4852 & 58 & $\mathrm{p}>0.05$ \\
\hline Diastolic B.P (mmHg) & $82 \pm 10$ & $82 \pm 10$ & 1 & 58 & $\mathrm{p}>0.05$ \\
\hline Haemoglobin (g/dl) & $13.4 \pm 0.8$ & $12.6 \pm 1.0$ & 3.4216 & 58 & $\mathrm{P}<0.05$ \\
\hline Packed Cell Volume (\%) & $40.0 \pm 2.5$ & $37.9 \pm 3.4$ & 2.7255 & 58 & $\mathrm{P}<0.05$ \\
\hline WBC (109/L & $6.4 \pm 2.3$ & $6.8 \pm 2.6$ & 0.6311 & 58 & $\mathrm{p}>0.05$ \\
\hline ESR (mm/hr) & $12 \pm 7.0$ & $18 \pm 10.6$ & 2.5871 & 58 & $\mathrm{P}<0.05$ \\
\hline
\end{tabular}

Table 1: Mean Comparison of Haematological Parameters and Blood Pressures of Male Students and Female Students 


\section{Medical Journal of Clinical Trials \& Case Studies}

Comparison of haematological parameters and blood pressures for the control subjects i.e. non students showed that almost all parameters investigated were comparatively similar ( $p>0.05)$ except the haemoglobin variable which showed a discrepancy $(\mathrm{p}<0.05)$ between the non-male students and non-female students as obtained as shown in Table 2.

\begin{tabular}{|c|c|c|c|c|c|}
\hline Parameters (Mean \pm SD) & Non Male Students & Non Female Students & t-test & DF & p-value \\
\hline Age (years) & $25 \pm 9$ & $25 \pm 8$ & 0 & 38 & $\mathrm{p}>0.05$ \\
\hline Systolic B.P (mmHg) & $124 \pm 13.5$ & $124 \pm 14$ & 0 & 38 & $\mathrm{p}>0.05$ \\
\hline Diastolic B.P (mmHg) & $81 \pm 10$ & $84 \pm 10$ & 0.9487 & 38 & $\mathrm{p}>0.05$ \\
\hline Haemoglobin (g/dl) & $13.4 \pm 1.0$ & $12.6 \pm 1.0$ & 2.5298 & 38 & $\mathrm{P}<0.05$ \\
\hline Packed Cell Volume (\%) & $40.7 \pm 3.5$ & $37.9 \pm 3.5$ & 2.5298 & 38 & $\mathrm{p}>0.05$ \\
\hline WBC (109/L & $8 \pm 2.6$ & $6.8 \pm 2.6$ & 1.4595 & 38 & $\mathrm{p}>0.05$ \\
\hline ESR (mm/hr) & $14.0 \pm 9.5$ & $18.4 \pm 10$ & 1.4266 & 38 & $\mathrm{p}>0.05$ \\
\hline
\end{tabular}

Table 2: Mean Comparison of Haematological Parameters and Blood Pressures of Non Male Students and Non Female Students.

Also, further evaluation of mean differences of blood pressure and haematological indices using the independent t-test among male students and non-male students showed mean difference $(\mathrm{P}<0.05)$ in the age, WBC and ESR while; the observation revealed an agreement in the mean values of the systolic blood pressure, diastolic blood pressure, haemoglobin and haematocrit (Packed Cell Volume) for both the male students and non-male students (Table 3 ).

\begin{tabular}{|c|c|c|c|c|c|}
\hline Parameters (Mean \pm SD) & Male Students N=30 & Non Male Students N=20 & t-test & DF & p-value \\
\hline Age (years) & $18 \pm 7$ & $25 \pm 9$ & 3.0879 & 48 & $\mathrm{P}<0.05$ \\
\hline Systolic B.P (mmHg) & $119 \pm 12$ & $124 \pm 13.5$ & 1.373 & 48 & $\mathrm{P}>0.05$ \\
\hline Diastolic B.P (mmHg) & $82 \pm 10$ & $81 \pm 10$ & 0.3464 & 48 & $\mathrm{P}>0.05$ \\
\hline Haemoglobin (g/dl) & $13.4 \pm 0.8$ & $13.4 \pm 1.0$ & 0 & 48 & $\mathrm{P}>0.05$ \\
\hline Packed Cell Volume (\%) & $40.0 \pm 2.5$ & $40.7 \pm 3.5$ & 0.8257 & 48 & $\mathrm{P}>0.05$ \\
\hline WBC (109/L & $6.4 \pm 2.3$ & $8 \pm 2.6$ & 2.2873 & 48 & $\mathrm{P}<0.05$ \\
\hline ESR (mm/hr) & $12 \pm 7.0$ & $14.0 \pm 9.5$ & 0.8572 & 48 & $\mathrm{P}<0.05$ \\
\hline
\end{tabular}

Table 3: Mean Comparison of Haematological Parameters and Blood Pressures of Male Students and Non Male Students.

On the other hand, same sex comparison of blood pressure and haematological variables between female students and non-female students as observed in this study revealed no indication of statistical inconsistency in all the mean values when tested with unpaired t-test (Table 4).

\begin{tabular}{|c|c|c|c|c|c|}
\hline \multirow{2}{*}{ Parameters (Mean \pm SD) } & Female Students & Non Female Students N=20 & \multirow{2}{*}{ t-test } & DF & p-value \\
\cline { 2 - 5 } & $\mathbf{N = 3 0}$ & $25 \pm 8$ & 0 & 48 & $\mathrm{P}>0.05$ \\
\hline Age (years) & $25 \pm 9$ & $124 \pm 14$ & 0 & 48 & $\mathrm{P}>0.05$ \\
\hline Systolic B.P (mmHg) & $124 \pm 14$ & $84 \pm 10$ & 0.6928 & 48 & $\mathrm{P}>0.05$ \\
\hline Diastolic B.P (mmHg) & $82 \pm 10$ & $12.6 \pm 1.0$ & 0 & 48 & $\mathrm{P}>0.05$ \\
\hline Haemoglobin (g/dl) & $12.6 \pm 1.0$ & $37.9 \pm 3.5$ & 0 & 48 & $\mathrm{P}>0.05$ \\
\hline Packed Cell Volume (\%) & $37.9 \pm 3.4$ & $6.8 \pm 2.6$ & 0 & 48 & $\mathrm{P}>0.05$ \\
\hline WBC (109/L & $6.8 \pm 2.6$ & $18.4 \pm 10$ & 0.1337 & 48 & $\mathrm{P}>0.05$ \\
\hline ESR (mm/hr) & $18 \pm 10.6$ & & & 0.05 \\
\hline
\end{tabular}

Table 4: Mean Comparison of Haematological Parameters and Blood Pressures of Female Students and Non Female Students. 


\section{Medical Journal of Clinical Trials \& Case Studies}

Overall mean comparison of the different study groups (both control and test) comprising male students, female students, male non students, and female non students using one way analysis of variance revealed evidence of significant mean difference in the age, haemoglobin, packed cell volume and ESR whereas, systolic blood pressure, diastolic blood pressure and white blood cell count were statistically not significant when the mean difference were compared.

\begin{tabular}{|c|c|c|c|c|c|c|}
\hline $\begin{array}{c}\text { Parameters (Mean } \pm \\
\text { SD) }\end{array}$ & $\begin{array}{c}\begin{array}{c}\text { Male } \\
\text { Students }\end{array} \\
\mathbf{N}=30 \\
\end{array}$ & $\begin{array}{c}\begin{array}{c}\text { Female } \\
\text { Students }\end{array} \\
\mathbf{N}=30\end{array}$ & $\begin{array}{c}\text { Male Non Students } \\
\mathbf{N}=\mathbf{2 0}\end{array}$ & $\begin{array}{l}\text { Female Non-Students } \\
\qquad \mathrm{N}=20\end{array}$ & F-value & p-value \\
\hline Age (years) & $18 \pm 7$ & $25 \pm 9$ & $25 \pm 9$ & $25 \pm 8$ & 5.046 & $\mathrm{P}<0.05$ \\
\hline SBP (mmHg) & $119 \pm 12$ & $124 \pm 14$ & $124 \pm 13.5$ & $124 \pm 14$ & 0.986 & $p>0.05$ \\
\hline DBP(mmHg) & $82 \pm 10$ & $82 \pm 10$ & $81 \pm 10$ & $84 \pm 10$ & 0.32 & $\mathrm{p}>0.05$ \\
\hline $\mathrm{Hb}(\mathrm{g} / \mathrm{dl})$ & $13.4 \pm 0.8$ & $12.6 \pm 1.0$ & $13.4 \pm 1.0$ & $12.6 \pm 1.0$ & 5.984 & $\mathrm{P}<0.05$ \\
\hline PCV (\%) & $40 \pm 2.5$ & $37.9 \pm 3.4$ & $40.7 \pm 3.5$ & $37.9 \pm 3.5$ & 4.806 & $\mathrm{P}<0.05$ \\
\hline WBC $\left(10^{9} / \mathrm{L}\right.$ & $6.4 \pm 2.3$ & $6.8 \pm 2.6$ & $8 \pm 2.6$ & $6.8 \pm 2.6$ & 1.697 & $p>0.05$ \\
\hline ESR (mm/hr) & $12 \pm 7.0$ & $18 \pm 10.6$ & $14.0 \pm 9.5$ & $18.4 \pm 10$ & 4.871 & $\mathrm{P}<0.05$ \\
\hline
\end{tabular}

Table 5: Comparison of the different study groups (both Control and Test) using one way analysis of variance.

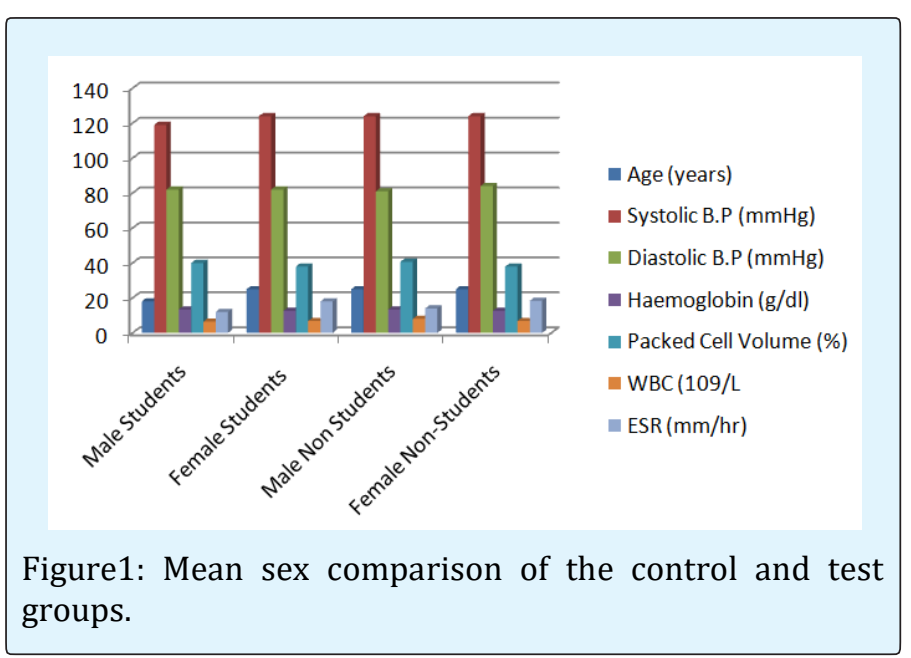

\section{Discussion}

The comparison of means via descriptive statistical analysis of the blood pressures and haematological parameters in students and controls revealed that haematological parameters and blood pressure varied among students and with respect to gender but with little or no statistical significance.

Generally, a combination of the mean assessment of the different study groups (both control and test) with respect to sex proved an indication of disparities in red cell indices of haemoglobin and packed cell volume. However, further evaluation demonstrated variance in age and the inflammatory marker -ESR although; the leucocyte population and the blood pressure did not record any discrepancy.
In a relative term, the different sex (male and female) comparison for both groups (i.e. students and control) revealed: Nonetheless, with respect to the student males and student females; the result amongst the student male and female showed age difference with the females older than the male students. Moreover, based on the blood pressure investigation, the result obtained in this present study appeared similar irrespective of the age and sex differences seen within these students. For the blood indices, the red cell indices showed to be significantly higher in males than the females whereas, the ESR was higher in females compared to males. However, the leucocyte was similar in both groups.

Similarly, comparison among the control group had analogous pattern like that of the student group i.e. showed no variation in the blood pressure and almost all the haematological parameters did not change significantly except haemoglobin for male and females.

Secondly, same sex comparison for both student and control groups showed; equivalent comparison of the sex for male students and control males showed unequal age distribution with the male students younger in age when compared to the control males however, the systolic blood pressure, diastolic blood pressure as well as the red cell indices of haemoglobin and PCV were comparable in both groups although the control exhibited a slightly raised systolic blood pressure with no statistical implication. Also, the control had higher white blood cell count and ESR than the students. This is opposed to the assumption that students are under pressure and stressed up in many ways that tend to probably affect their blood pressures and in-turn their haematological parameters. 


\section{Medical Journal of Clinical Trials \& Case Studies}

However, on the other hand these could be linked to probably large amount of course/school work load tagged with time and date ultimatum for submission, eaten of junk, smoking, taking alcohol and other lifestyle that predisposes them to massive stress and disease outcome. On the other hand, the female students correspondingly matched their control female counterparts in all results of blood pressure and haematological parameters with no exception in age. However, the reason for these is not very clear clinically, but it could be argued literally that it is most probably believed that, females are stronger and better equipped to withstand and manage stress in any situations they found themselves, than their male counterpart that respond to issues fiercely, and most times backed it up with actions. In addition, in family settings for example, women takes care of children, house, and cook and do other incidental duties, infect they are good in multi-tasking with potential stress management skill than men.

Furthermore, the normal blood pressure obtained among students in this study agrees with the fact that high blood pressure is associated with increase in age according to some studies also, the slightly raised nonsignificant blood pressure of the control group is in line with prior studies that had established pre HTN and HTN in the early stages of life, which could persist into adulthood $[1,6,7]$.

The report of indices of the erythrocyte population obtained in this study showed substantial difference between males and females notwithstanding the group for both the Haemoglobin and haematocrit (Packed Cell Volume) respectively. Nonetheless, this present result agrees with some studies in the past which previously reported that, sex dissimilarities occur in the different haematological parameters even in healthy individuals in Afro region [24-26]. Thus, with respect to the above affirmed statement, it is strongly probably believed that, these variations could have been attributed to different conditions for instance; the index packed cell volume which is one of haematological determinants which tends to vary in response to blood pressure. It has been reported that haematocrit and specific gravity of whole blood lowers significantly in healthy Nigerian females compared to males. Moreover, the reason for this sex variation in red cell indices is not far from the physiological functioning of the female body system [27].

Also, the result of the total white blood cell count as obtained in this present study was normal although, the control subjects recorded higher values of the normal reference range as revealed in this study, thus, by implication normotension can maintain normal white cell count excluding other confounders. This present study is in consonance with the work of Al-Muhana and colleagues (2006), which reported leukocytosis in hypertension instead of normotension among youths and this has been implicated to be prospectively related with cardiovascular disease as reported in their study on the haematological, lipid profile and other biochemical parameters in normal and hypertensive subjects among the population of the eastern province of Saudi Arabia [28]. However, the work of Al-Muhana and colleagues (2006) result correlated with the findings of Silver and colleagues (2013) which reported that total white cell count was higher in hypertensive patients than normal subjects. The result from this present study showed that the subjects had no evidence of inflammation from the report of the white blood cell count. However, according to the finding of Rajkumari, et al. (2000) attributed the increase in white blood cell to a significant increase in inflammatory markers like total white blood cell count [29]. Also, a normal blood pressure was observed for the students whereas, a slightly raised reading was observed for the non-students (controls). However, Farhana, et al. (2009) in a study on the relationship between white blood cell counts and ESR with high blood pressure showed that total white cell counts were significantly higher in test group compared to control group population [30].

Furthermore, many prospective and retrospectives studies had showed a direct relationship between white cell count and risk of hypertension as asserted by Sweetnam, et al. (2000), although, the mechanisms linking white cell counts to cardiovascular risk are not well understood according to the researchers. However, increased number and activation of circulating leukocytes could contribute to atherogenesis by increased adhesion to and damage of the endothelium, and by disturbance of micro-vascular flow [31]. According to a study on age, gender and risk matched subjects, mean total white blood cell count was higher in patients with high blood pressure than in normotensive control subjects [32]. In addition, a study by Jia, et al. (2004) reported a strong relationship and an increase in total leukocyte count especially neutrophils in patients with angiographically established atherosclerosis [33].

Moreover, the non-specific inflammatory marker erythrocyte sedimentation rate varied amongst male and female students as the females had higher rate when compared to their male counterparts. One of the key causes of significantly raised ESR could be acute and chronic inflammatory conditions such as hypertensive disorder, this is in agreement with the slightly raised 


\section{Medical Journal of Clinical Trials \& Case Studies}

blood pressure (pre-hypertension) observed among the controls alongside the value of their ESR when compared with the student values [34]. Several studies have reported an increased ESR in hypertension. In a study on Westergren ESR and haematocrit, ESR was described as a possible marker of atherosclerosis and a strong predictor of coronary death among subjects in apparently good health. Because it is not influenced by the haematocrit value, ESR could be a better marker of inflammation. ESR have emerged as a strong long and short term predictor of coronary heart disease, it could also be used as a prognostic information among healthy men and also among men with a positive exercise ECG test and lastly among men with angina pectoris [35]. Bhatia, et al. (2004) in a related study reported an elevated ESR in hypertensive patients compared to the control subjects. An accelerated erythrocyte aggregation is caused by large asymmetrical plasma proteins, inhibiting the negative electrical forces that normally keep the erythrocytes apart. Atherosclerosis as an inflammatory disease results in higher levels of ESR. According to a study by Natali, et al. (2003) ESR was progressively higher in the presence of angiographically documented major narrowing of vessel disease in patients indicating that ESR is an independent correlate of coronary atheroscelerosis [36]. Nonetheless, the findings from this study were further underpinned by Kere, et al. (2011) in their study on haematological parameters in hypertensive patients. They demonstrated that the mean erythrocyte sedimentation rate (ESR) in hypertensive subjects was statistically higher than that of normotensive; and this present study did not record elevated ESR nor BP rather slight variation which is not statistically significant thus, subjects revealed mainly normal values within reference range or slightly above [37]. This is in conformity with the prior works. They concluded that patients with high blood pressure tend to demonstrate erythrocytes marked with rouleaus formation and therefore, high erythrocyte sedimentation rate is recorded. The ESR in females was significantly higher compared to that of the males. This finding supports the report that moderately raised erythrocyte sedimentation rate can sometimes be found in healthy people particularly those living in tropical countries and thus, a normal ESR cannot exclude disease condition though [34].

\section{Conclusion}

The study has shown that haematological parameters and blood pressures in students remain within the acceptable baseline values. This entails that variations or deviations from normal values will only occur in an unhealthy physiological body condition which may arise from stress associated with the University system in Nigeria. Similarly, the non-students tend to have moderately higher blood pressures. This is probably believed to be associated with the nature of their activities and kind of job they do.

\section{References}

1. Kitai E, Vinker S, Halperin L, Meidan A, Grossman E (2007) Pre-hypertension is a common phenomenon: National database study. Isr Med Association J 9(1): 8-11.

2. Egan BM, Zhao Y, Axon RN (2010) US trends in prevalence, awareness, treatment, and control of hypertension, 1988-2008. JAMA 303(20): 2043-2050.

3. Gu D, Reynolds K, Wu X, Chen J, Duan X, et al. (2002) Prevalence, awareness, treatment, and control of hypertension in china. Hypertension 40(6): 920-927.

4. The World Health Report (2002) Reducing risks, promoting healthy life. Geneva Switzerland World Health Organization.

5. Kaerney PM, Whelton M, Reynolds SK, Munter P, Whelton PK, et al. (2005) Global burden of hypertension: An analysis of world wide data. Lancet 365(9455): 217-223.

6. Ejike CE, Ugwu CE, Ezeanyika LU (2010) Variations in the prevalence of point (pre) hypertension in a Nigerian school-going adolescent population living in a semi-urban and an urban area. BMC Pediatric 10: 13.

7. Culhane-Pera KA, Moua M, DeFor TA, Desai J (2009) Cardiovascular disease risks in Hmong refugees from Wat Tham Krabok, Thailand. J Immigr Minor Health 11(5): 372-379.

8. Fuentes RM, Notkola IL, Shemeikka S, Tuomilehto J, Nissinen A (2002) Tracking of systolic blood pressure during childhood: A 15 year follow up population based family study in Eastern Finland. J Hypertens 20(2): 195-202.

9. Silva FM, Budo MLD, Silveira CL, Badke MR, Beuter M (2013) Hipertensão: condição de não doença - o significado da cronicidade na perspectiva dos sujeitos. Texto Contexto Enferm 22(1): 123-131.

10. Tesfaye F, Nawi NG, Van Minh H, Byass P, Berhane $Y$, et al. (2007) Association between body mass index 


\section{Medical Journal of Clinical Trials \& Case Studies}

and blood pressure across three populations in Africa and Asia. J Hum Hypertens 21(1): 28-37.

11. Lauer RM, Clarke WR, Mahoney LT, Witt J (1993) Childhood predictors for high adult blood pressure. The Muscatine study. Pediatr Clin North Am 40(1): 23-40.

12. Sajjad R, Muhammad A, Muhammad F, Saad E, Rabia $M$, et al. (2010) Dietary modification, body mass index (BMI), blood pressure (BP) and cardiovascular risk in medical students of a government medical college of Karachi. J Pak Med Association 60(11): 970-974.

13. Gasparotto GS, Gasparotto LPR, Rossi LM, Moreira NB, Bontorin MS, et al. (2013) Association between moment of the undergraduate course and cardiovascular risk factors in university students. Rev Latino-Am Enfermagem 21(3): 687-694.

14. Lima ACS, Araujo MFM, Freitas RWJF, Zanetti ML, Almeida PC, et al. (2014) Risk factors for Type 2 Diabetes Mellitus in college students: association with sociodemographic variables. Rev Latino-Am Enfermagem 22(3): 484-490.

15. Valberg LS, Sorbie JL, Ludwig J, Pelletier (1976) Serum ferritin and the iron status of Canadians. Canadian Medical Association J 114(5): 417-421.

16. Rushton DH, Dover R, Sainsbury AW, Norris MJ, Gilkes $\mathrm{JJH}$, et al. (2001) Why should women have lower reference limits for Haemoglobin and forritin concentrations than men?. British Medical Journal 322(7298): 1355-1357.

17. Caplea A, Darcie Seachrist, Dunphy G, Ely D (2001) Sodium-induced rise in blood pressure is suppressed by androgen receptor blockade. Am J Physiol Heart Circ Physiol 280 (4): 1793-1801.

18. Rosenson RS, Wolff 0, Green D, Boss AH, Kensey KR (2004) Aspirin. Aspirin does not alter native blood viscosity. J Thromb Haemost 2(2): 340-341.

19. Van Berge-Landry HM, Bovbjerg DH, James GD (2008) Relationship between waking-sleep blood pressure and catecholamine changes in African-American and European-American women. Blood Press Monitor 13 (5): 257-262.

20. Upasanaba J, Jadeja JM (2011) Coniparative study of haemoglobin concentration in hypertensive and normo \tensive subjects. British Medical Journal 23: $12-28$.

21. Nwisi R (2013) Diobu Timber Market: A Den of Robbers, Kidnappers. The Nations Newspaper.

22. Chobanian AV, Bakris GL, Black HR, Cushman WC, Green LA, et al. (2003) The seventh report of the joint national committee on prevention, detection, evaluation, and treatment of high blood pressure: The JNC 7 report. JAMA 289(19): 2560-2572.

23. Cardiologia SBD, Hipertensao SBD, Nefrologia SBD (2010) VI Diretrizes Brasileira de Hipertensao. Arq Bras Cardiol 95(1): 1-51.

24. Ingram Gic (1961) A suggested schedule for the rapid investigation of acute haemostatic failure. Journal of Clinical Pathology 14(4): 356-360.

25. Dacie J V, Lewis SM (1991) Practical Haematoloqy. $7^{\text {th }}$ (Edn.), Churchill Living stone Edinburqh.

26. Dapper DV (2002) Haemorheological parameters in some hypertensive Nigerians. MSc. Thesis University of Benin Benin Nigeria.

27. Guyton, Hall (2000) Medical Physiology. $7^{\text {th }}$ (Edn.), Elsevier-Saunders Philadelphia.

28. Al-Muhana FA, Larbi EB, Al-Ali AK, Al-Sultan A, AlAteeeq S, et al. (2006) Haematological, lipid profile and other biochemical parameters in normal and hypertensive subjects among the population of the eastern province of Saudi Arabia. East African Medical Journal 83(1): I 44-148.

29. Rajkurnari R, Laishram 0 (2006) Hypertensive Leukocytosis. Bullish Medical Journal 2: 23 -30.

30. Shahzad F1, Tawwab S, Abbas A (2009) Relationship of White blood cell counts, haemoglobln and Erythocyte Sedimentation Rate with ischernic heart disease. Journal of Ayub Medical College Abbottabad 21(3): 59-62.

31. Sweetnam PM, Thomas IIF, Yarnell JW, Baker IA, Elwood PC (1997) Total and differential leukocyte counts as predictors of ischemic heart disease: the Caerphilly and Speedwell studies. America Journal of Epidemiology 145(5): 416-421.

32. Grau AJ, Boddy AW, Dukovic DA, Buggle F, Lichy C, et al (2004) Leukocyte count as an independent 


\section{Medical Journal of Clinical Trials \& Case Studies}

predictor of recurrent ischemic events. Stroke 35(5): 1147-1152.

33. Jia E, Yang Z, Yuan B, Zang X, Rong-hu W, et al. (2005) Relationship between leukocyte count and angiographical characteristics of coronary atherosclerosis. Acta Pharmacological Sinica 26 (9): 1057-1062.

34. Monica C (2003) District Laboratory Practice I topical Countries. 6 $6^{\text {th }}$ (Edn.), Cambridge University Press, United Kingdom, pp: 299-331.

35. Erikssen, G, Liestol, K, Bjornholt JV, Stormorken H, Thaulow E, et al. (2000) Erythrocyte sedimentation rate: a possible marker of atherosclerosis and a strong predictor of coronary heart disease mortality. European Heart Journal 21(19): 1614-1620.

36. Natali A, Abbate A, Ferrannini E (2003) Erythrocyte sedimentation rate, coronary atherosclerosis, and cardiac mortality. European Henri Journal 24(7): 639648.

37. Grossman E, Messedj FH (2012) Drug-induced Hypertension: An Unappreciated Cause of Secondary Hypertension. Am J Med 125(1): 14-22. 